Original Research Paper

\title{
Factors that Influence Rice Production and Technical Efficiency in the Context of an Integrated Crop Management Field School Program
}

\author{
${ }^{1}$ Moh. Nur Rasyid, ${ }^{2}$ Budi Setiawan, ${ }^{2}$ Moch. Muslich Mustadjab and ${ }^{2}$ Nuhfil Hanani \\ ${ }^{1}$ The Doctoral Program of Universitas Brawijaya, Indonesia \\ ${ }^{2}$ Department of Agriculture Economic, University of Brawijaya, Indonesia
}

\author{
Article history \\ Received: 05-10-2016 \\ Revised: 02-11-2016 \\ Accepted: 05-11-2016 \\ Corresponding Author: \\ Moh. Nur Rasyid \\ The Doctoral Program of \\ Universitas Brawijaya, \\ Indonesia \\ Email: rasyid.m52@yahoo.com
}

\begin{abstract}
This research estimates the effect of production input on rice production and the effect of socio-economic factors on the technical efficiency of rice farms in the program of the Integrated Crop Management Field School (ICMFS). Data were collected from 78 rice farmer household heads from two randomly chosen villages in Indonesia. The results show that seed, fertilizer, pesticide and labor significantly positively affect rice production. Socioeconomic factors such as farmer age, education and experience, the number of household members and the frequency of visiting the ICMFS field laboratory had significant positive effects on the level of technical efficiency. Thus, the ICMFS, by continuing to increase ICMFS program to the people of rural areas and by taking into account socio-economic status of farmers, can improve rice farming production and efficiency.
\end{abstract}

Keywords: Field School, Socio-Economic Status, Technical Efficiency,

Rice Production

\section{Introduction}

Rice is a basic need for the people of Indonesia and the main product produced by most farmers; thus, increasing rice production to achieve food self-sufficiency is an important goal for the country. Within the next decade, Indonesia should be able to independently meet the needs of the community. Achieving this increase might best be done through an increase in productivity potential and the potential availability of new land that could be used as irrigated land for rice.

The policy of the central government in the development of rice farms, including efforts to increase rice production, is focused on the application of the Integrated Crop Management Field School (ICMFS). Parigi Moutong organized ICMFS, but the resulting productivity remains below the expected productivity. Productivity of rice in Parigi Moutong Regency is 5.24 tons/ha, below the potential of $>7$ tons/ha for rice. Therefore, the income of rice farms has not yet significantly increased (DGFC, 2012). One of the problems identified as limiting production is an inefficient use of production inputs. Increasing productivity could thus be done by increasing the efficiency of production input usage. Production inputs of seeds, fertilizer, pesticide and labor may affect agricultural production in Indonesia (Effendy, 2010; 2015).
Directly and indirectly increase productivity and income of participating communities and indirectly increase income of communities in the surrounding area. Based on the results noted above, it appears that the ICMFS program could best improve rice production through a focus on production inputs. The objective of this research is to estimate the potential effect of production inputs on rice production and also to estimate the socio-economic factors that can affect the technical efficiency of rice farms in the ICMFS program.

\section{Research Methods}

Research was conducted in Parigi Moutong Regency. Two villages, Dolago Village and Tolai Village, were randomly selected for use in the study. For both villages, sample units consisted of Household Heads $(\mathrm{HH})$ that lived in the villages and farmed rice. A total of $385 \mathrm{HH}$ entered the ICMFS group: 187 in Dolago Village and 198 in Tolai Village.

The appropriate sample size for each village was calculated using the formula from Parel et al. (1973):

$n=\frac{N Z^{2} \sigma^{2}}{N d^{2}+Z^{2} \sigma^{2}}$ 
Where:

$n=$ Number of samples for each village

$N=$ population size of each village

$Z=$ Standard normal deviate at the desired confidence level $(90 \%)=1.645$

$\sigma^{2}=$ Population variance

$d^{2}=$ Standard error $(0.1)$

Based on this, the number of samples used in Dolago Village was $36 \mathrm{HH}$ and in Tolai Village was $42 \mathrm{HH}$ (Table 1).

The frontier production function was used to address the research objective. The approach of the frontier production function is based on a model developed by Coelli et al. (2005), which follows the form of the CobbDouglas model:

$$
\ln Y_{i}=\lambda_{0}+\sum_{j=1}^{k} \lambda_{j} \ln X_{j i}+\left(V_{i}-U_{i}\right)
$$

The specific equation considered in this study was:

$$
\begin{aligned}
& \ln (P R O D)=b_{0}+b_{1} \ln (S E E D) \\
& +b_{2} \ln (P U)+b_{3} \ln (P E S T)+b_{4} \ln (L)+\left(V_{i}-U_{i}\right)
\end{aligned}
$$

Where:

$$
\begin{aligned}
P R O D= & \text { Rice production }(\mathrm{kg}) \\
S E E D= & \text { Rice seed }(\mathrm{kg}) \\
P U^{\prime}= & \text { Fertilizer }(\mathrm{kg}) \\
P E S T= & \text { Pesticide (liter) } \\
L= & \text { Labor }(\text { days } \times \text { people working per day }=\mathrm{DPW}) \\
V_{i}= & \text { Random error term } \\
U_{i}= & \text { Random variable that represents technical } \\
& \text { inefficiency of sample } i
\end{aligned}
$$

Technical efficiency of farmer $i$ 's farm production is estimated as (Coelli et al., 2005):

$$
T E_{i}=\frac{y_{i}}{y_{i}^{*}}=\frac{\exp \left(x_{i} \beta+v_{i}-u_{i}\right)}{\exp \left(x_{i} \beta+v_{i}\right)}=\exp \left(-u_{i}\right)
$$

where, $y_{i}$ is the observed production and $y_{i}{ }^{*}$ is the expected frontier production based on the stochastic frontier production function.

A multiple linear regression model was then used to estimate socio-economic effects on technical efficiency:

$$
\begin{aligned}
& T E=\delta_{0}+\delta_{1} U P+\delta_{2} P D K+\delta_{3} P E N G A \\
& +\delta_{4} J A R T P+\delta_{5} P D P+\delta_{6} \text { KICMFS }+\varepsilon_{i}
\end{aligned}
$$

Where:

$$
T E=\text { The estimated technical efficiency level }
$$

$$
\begin{aligned}
U P & =\text { Age of farmer (years) } \\
P D K= & \text { Education (elementary Vs. beyond } \\
& \text { elementary) } \\
P E N G A= & \text { Experience of farms (years) } \\
J A R T P= & \text { Number of productive household members } \\
P D P= & \text { Income (IDR) } \\
\text { KICMFS }= & \text { Participation in ICMFS field laboratory } \\
& \text { visits (frequency) }
\end{aligned}
$$

\section{Results and Discussion}

\section{Factors Affecting Rice Production}

The analysis results of stochastic frontier production function of Cobb-Douglas model on rice farms are shown in Table 2.

Seed quality and quantity had significant effects on rice production. Increasing seed numbers increased the population number of rice crops and thus increased rice production. This research is relevant to the research of Effendy (2010).

Fertilizer had a significant effect on rice production. Additional fertilizer on agricultural land increased the nutrients nitrogen, sulfur and potassium in the soil that were needed by rice. This result agrees with the research of Li et al. (2008; Effendy, 2015).

Pesticides significantly affected rice production, reducing damage to rice panicles by pests and disease, to maintain production. Pesticide use to control pests and diseases of rice crops is necessary to prevent crop failure. Our results support the research of Dewi and Idris (2005), but are contrary to the research of Khazanani and Nugroho (2011).

Labor affects rice production (Li et al., 2008; Khazanani and Nugroho, 2011; Effendy, 2010; 2015). Additional labor allows rice farm activities, for example, soil tillage, weeding, fertilization, pest and disease control, to be implemented in a timely manner that in turn will increase rice production. Additional labor increases rice production, which has implications for increasing a farmer's income.

\section{Factors Affecting Technical Efficiency}

The level of technical efficiency of rice farms was analyzed in conjunction with factors affecting production using the stochastic frontier production function of the Cobb-Douglas model. Data were analyzed using multiple regression analysis in SPSS software, version 18.00 and are shown in Table 3.

The age of farmers had a positive effect on the level of technical efficiency of rice farms in the ICMFS program. Age of farmers was positively correlated with rice farm experience and increased experience and knowledge led to increased technical efficiency. This indicates that if a farmer consistently grows rice, they will increase technical efficiency over time. 
Table 1. Number of samples

\begin{tabular}{llllllll}
\hline Village & $\mathrm{N}$ & $\mathrm{Z}$ & $\mathrm{Z} 2$ & $\mathrm{~d}$ & $\mathrm{~d} 2$ & $\mathrm{var}$ & $\mathrm{n}$ \\
\hline Dolago & 187 & 1.645 & 2.71 & 0.10 & 0.01 & 0.161 & 36 \\
Tolai & 198 & 1.645 & 2.71 & 0.10 & 0.01 & 0.196 & 42 \\
Total & 385 & & & & & & 78 \\
\hline
\end{tabular}

Table 2. Parameter estimates based on the stochastic frontier production function of the Cobb-Douglas model on rice farms

\begin{tabular}{llcc}
\hline Variable & Coefficient & Standard-error & T-ratio \\
\hline Intercept & 8.681 & & T-table (5\%) \\
Seed & 0.465 & 0.031 & $14.883^{*}$ \\
Fertilizer & 0.359 & 0.023 & $15.348^{*}$ \\
Pesticide & 0.628 & 0.034 & $18.299 *$ \\
Labor & 0.251 & 0.026 & $9.702^{*}$ \\
Sigma-squared & 0.160 & 0.033 & $4.883^{*}$ \\
Gamma & 0.976 & 0.025 & $38.284^{*}$ \\
Log likelihood function & 5.998 & & 1.993 \\
LR & 12.420 & $x^{2}=9.49$ & 1.993 \\
\hline
\end{tabular}

$*=$ Significant at $\alpha 5 \%$ two-tail test

Table 3. Parameter estimation for technical efficiency level of rice farmers in ICMFS program

\begin{tabular}{lllll}
\hline Variable & Coefficient & Standard Error & t- count & $\mathrm{p}$ \\
\hline Intercept & 0.747 & & & \\
Age & 0.073 & 0.017 & $4.280^{*}$ & 0.000 \\
Education & 0.081 & 0.015 & $5.422^{*}$ & 0.000 \\
Experience & 0.039 & 0.013 & $3.044^{*}$ & 0.003 \\
Number of Family Members & 0.056 & 0.014 & $3.911^{*}$ & 0.000 \\
Income & 0.012 & 0.012 & $2.917^{\text {ns }}$ & 0.313 \\
Visits to the Laboratory ICMFS & 0.031 & 0.011 & 0.005
\end{tabular}

$\mathrm{F}_{\text {count }}=24.674 * \mathrm{p}=0.000$

Adjusted Determinant coefficient (R2) 0.648

* Significant at $\alpha 1 \%$

Farmer education level was also positively related to the level of technical efficiency of rice farms in the ICMFS program. Farmers that were educated beyond the level of elementary school had, on average, farms with levels of technical efficiency $0.081 \%$ higher than the farms of farmers who were not educated beyond elementary school. This is likely because a higher education level of farmers provides them with higher technical and management capabilities to absorb information technology. The higher the education level of farmers, the better their ability to apply technology and allocate available resources efficiently. This result agrees with that of Mohapatra (2011; Krasachat, 2012), who concluded that education significantly contributed to increasing the efficiency of agriculture.

Experience working on rice farms had a positive effect on the level of technical efficiency of rice farms in the ICMFS program. This research supports research of Wollni and Brümmer (2012), who concluded that the most important factor affecting the level of technical efficiency of coffee farms in Costa Rica was farmer experience in the cultivation of coffee.

The number of family members also positively affected the level of technical efficiency of rice farms in ICMFS program. Research of Bello et al. (2012), which identified factors affecting the use of rice farming technology in Nasarawa, Central Nigeria. Characteristics of farmers such as age, size of household, social participation, agricultural experience, land area, income of farms and extension contacts, explained $67.0 \%$ of variation in the application of rice technology by farmers.

The income of farms was not related to the level of technical efficiency for rice farms in the ICMFS program, likely because there was little variation in income among rice farms in this study. Higher frequency of ICMFS field laboratory visits led to increased levels of technical efficiency for rice farms in the ICMFS program. Rahman and Hasan (2008) similarly concluded that providing an agricultural information source could increase the technical efficiency of farmers in Bangladesh. Furthermore, Jahan and Pemsl (2011) found that training had significant positive effects on the technical efficiency of farmers, total farmer productivity and the net income of small-scale farmers in Bangladesh. Rahman and Rahman (2008) suggest that increasing of extension services and the application of technology could increase the technical efficiency of farmers and thus increase rice production in Bangladesh.

The ICMFS field laboratory provided a non-formal education. Non-formal education can improve the ability of rice farmer to make decisions and their ability to 
apply the technology on their farms and thus increase the technical efficiency of farms.

\section{Conclusion}

Seeds, fertilizer, pesticide and labor all had significant positive effects on rice production. Socioeconomic factors, such as the age of farmers, their education level and experience level, number of family members and frequency of ICMFS field laboratory visits had significant positive impacts on the level of technical efficiency of rice farms. Based on these results, the ICMFS is expected to continue increasing ICMFS programs to rural communities, paying attention to the socioeconomic status of farmers.

\section{Acknowledgement}

The authors would like to thank the reviewers who had took time to perfect this article.

\section{Author's Contributions}

Moh. Nur Rasyid: Contributions to conception, design, and acquisition of data and Analysis and interpretation of data.

Budi Setiawan Hanani, Moch. Muslich Mustadjab and Nuhfil Hanani: Contribute in drafting the article or reviewing it critically for significant intellectual content.

\section{Ethics}

This paper is original and authors confirm that all of other authors have read and approved the paper.

\section{References}

Bello, M., E.S. Salau and L. Ezra, 2012. Analysis of factors influencing discontinuance of technology adoption: The situation with some nigerian farmers. Sustainable Agric. Res., 1: 292-300. DOI: $10.5539 /$ sar.v1n2p292

Coelli, T.J., D.S.P. Rao, C.J. O'Donnell and G.E. Battese, 2005. An Introduction to Efficiency and Productivity Analysis. 2nd Edn., Springer Science and Business Media, New York, ISBN-10: 0387242651, pp: 349.

Dewi, S. and Idris, 2005. Production efficiency of rice farms system in rice field of technical irrigation.

DGFC, 2012. Technical Guidelines for Integrated Crop Management Field School (ICMFS rice and rice fields). Ministry of Agriculture Directorate General of Food Crops.
Effendy, 2010. Factor efficiency of production and income level of rice fields in masani village poso pesisir subdistrict poso regency. J. Agroland, 17: 233-240.

Effendy, 2015. Increasing of cocoa farmers household income with two stage least squares method. Modern Applied Sci., 9: 120-127.

DOI: $10.5539 /$ mas.v9n6p120

Jahan, K.M.E. and D.E. Pemsl, 2011. The impact of integrated aquaculture-agriculture on small-scale farm sustainability and farmers' livelihoods: Experience from Bangladesh. Agric. Syst., 104: 392-402. DOI: 10.1016/j.agsy.2011.01.003

Khazanani, A. and Nugroho, 2011. Analysis efficiency usage of chili farms production factors of temanggung regency. J. Develop. Econom., 5: 17-22.

Krasachat, W., 2012. Organic production practices and technical inefficiency of durian farms in Thailand. Procedia Econom. Finance, 3: 445-450. DOI: $10.1016 / \mathrm{S} 2212-5671(12) 00178-5$

Li, X., Y. Luo, Q. Gao, S. Dong and X. Yang, 2008. Farm production growth in the upper and middle parts of the yellow river basin, China, during 19801999. Agric. Sci. China, 7: 344-355.

DOI: $10.1016 /$ S1671-2927(08)60075-9

Mohapatra, R., 2011. Farmers' education and profit efficiency in sugarcane production: A stochastic frontier profit function approach. IUP J. Agric. Econom., 8: 18-35.

Parel, C.P., G.C. Caldito, P.L. Ferrer, G.G. De Guzman and C.S. Sinsioco et al., 1973. Sampling design and procedures. Documentation. Agricultural Development Council, New York.

Rahman, S. and M. Rahman, 2008. Impact of land fragmentation and resource ownership on productivity and efficiency: The case of rice producers in Bangladesh. Land Use Policy, 26: 95-103. DOI: $10.1016 /$ j.landusepol.2008.01.003

Rahman, S. and M.K. Hasan, 2008. Impact of environmental production conditions on productivity and efficiency: A case study of wheat farmers in Bangladesh. J. Environ. Manage., 88: 1495-1504. DOI: 10.1016/j.jenvman.2007.07.019

Wollni, M. and B. Brümmer, 2012. Productive efficiency of specialty and conventional coffee farmers in Costa Rica: Accounting for technological heterogeneity and self-selection. Food Policy, 37: 67-76. DOI: 10.1016/j.foodpol.2011.11.004 